\title{
F-WAVE IN THE UPPER EXTREMITIES OF PATIENTS WITH PRIMARY TORSION DYSTONIA
}

\author{
Received January 10, 2014
}

We investigated characteristics of the F-waves in the upper limbs of patients suffering
from primary torsion dystonia (PTD) by means of surface-electrode electromyography.
Single electric stimulation was used to obtain optimum M-responses from the m. abductor
pollicis brevis (median nerve) and m. abductor digiti minimi (ulnar nerve). Ten consecutive
supramaximum electrical stimuli were applied to each nerve to obtain F-waves from the
wrist. In general, the registered M-response latencies and amplitudes, as well as conduction
velocities via all inspected nerves, demonstrated no significant deviations from the normal
ranges. Nearly all investigated patients, except one, had normal F-wave minimal latencies.
The mean amplitudes of F-waves from both median and ulnar nerves were higher than the
average F-wave amplitudes described in the literature. The frequency of occurrence of
F-waves in both median and ulnar nerves was greater than in the norm. According to our
results, it can be concluded that the amplitude and, to some extent, frequency rather than the
latency of F-waves are important in the studies of patients with PTD. Increased amplitudes
and frequencies reveal changes in the excitability of alpha motoneurons, which could be
accepted as a measure of a disturbed interneuronal balance probably caused by alterations in
the suprasegmental control mechanisms related to PTD.

Keywords: surface electromyography, F-wave, upper extremities, primary torsion dystonia, latency, amplitude, frequency of occurrence.

\section{INTRODUCTION}

Dystonia is a movement disorder characterized by intermittent or sustained simultaneous muscle contractions of opposing muscles, which result in twisting and repetitive movements, abnormal posture, or both. When no etiological factor can be identified, this type of dystonia is referred to as primary torsion dystonia (PTD) [1]. The disorder may affect any part of the body (neck, face, trunk, or extremities) [1, 2], often causing serious disability.

Electrophysiological studies significantly contribute to revealing the pathophysiology of PTD. Most of the results, however, are not routinely used in clinical practice [3]. Therefore, we decided to investigate the spinal F-waves in the upper extremities of PTD patients; surface-electrode electromyography was used. This technique is widely available, noninvasive, and safe; at the same time, it can provide

\footnotetext{
${ }^{1}$ UMHATNP "St. Naum," Sofia, Bulgaria.

Correspondence should be addressed to N. Semerdjieva

(e-mail: nikolina.semerdjieva@gmail.com).
}

researchers with valuable information on the state of spinal reflexes. There is some evidence suggesting that $\mathrm{F}$-wave studies could provide an independent assessment of the excitability of motor neurons $[4,5]$. An increase in this index is reflected in the increased F-wave amplitude, although this relationship is not always straightforward [6].

\section{METHODS}

We used coupled two-channel EMG devices from Teca Synergy and Medtronic (USA) connected to personal computers for amplification and analysis of the signals. Surface electrodes for electrical stimulation of the median and ulnar nerves were located on the respective projections.

For stimulation of the median (C7-8) and ulnar (C8Th1) nerves, supramaximum single electrical stimuli (40-60 mA, $0.2 \mathrm{msec})$ were used to obtain optimum M-responses from the $m$. abductor pollicis brevis and $m$. abductor digiti minimi, respectively. Then, we applied 10 supramaximum ( $80-100 \mathrm{~mA}, 0.2 \mathrm{msec})$ consecutive electrical stimulations for each nerve to 
obtain F-waves recorded from the wrist level [7].

As the normal range of the median $\mathrm{F}$-wave minimal latency in the wrist, we used the mean value of 26.6 (24.4-28.8) $\mathrm{msec}$, up to $31 \mathrm{msec}$, and as the respective range of the ulnar F-wave latency, 27.6 (25.4-29.8) msec, up to $32 \mathrm{msec}$ [8].

As the normal range of frequency of occurrence of F-waves for both median and ulnar nerves, we took into account a value of $55-79 \%$ [7]. The maximum amplitude of the F-wave varies from 0.4 to $0.6 \mathrm{mV}$ [14]; thus, for the F-wave average amplitude we used the range $0.15-0.3 \mathrm{mV}[7,8]$. According to different authors, the average median F-wave amplitude in the wrist is about $288.3(155.0-421.6) \mu \mathrm{V}$ or about 225 $\mu \mathrm{V}$ [7]. The same values for the ulnar F-wave were reported to be from $150 \mu \mathrm{V}$ to $209 \mu \mathrm{V}$ [7].

Numerical data were statistically analyzed using SPSS (version 13.0) software. The parametric independent-sample $t$-test and nonparametric Kolmogorov-Smirnov, Shapiro-Wilk, and MannWhitney tests were used for intergroup comparisons; $P=0.05$ was taken as the index of statistical significance of the difference.

\section{RESULTS}

A total of 36 patients with PTD was examined; their mean age was $53 \pm 14$ years(mean \pm s.d.). The group included 23 women and 13 men. The average duration of the disease was $3.8 \pm 0.6$ years. Thirteen investigated patients suffered from cervical dystonia; blepharospasm was diagnozed in 78 patients, oromandibular dystonia in two patients, and upper limb dystonia, also in two patients. Nine patients suffered from segmental dystonia, and two patients from generalized dystonia.

The distal latency of M-responses recorded from the m. abductor pollicis brevis (median nerve) varied within the range 3.1 to $4.75 \mathrm{msec}$ (average $3.7 \pm 0.6 \mathrm{msec}$ ). The proximal latency of the M-response from this muscle varied between 6.2 and $8.8 \mathrm{msec}(7.5 \pm 0.95 \mathrm{msec})$. The conduction velocity via the median nerve varied between 48.0 and $70.2 \mathrm{~m} / \mathrm{sec}$, average $58.6 \pm 6.3 \mathrm{~m} / \mathrm{sec}$. The distal amplitude of median M-response was 2.0 to $11.5 \mathrm{mV}$, average $6.0 \pm 2.9 \mathrm{mV}$; there was one patient with a distal amplitude of $2.0 \mathrm{mV}$ and decreased proximal amplitude $(2.0 \mathrm{mV})$. This patient suffered from axonal neuropathy of the right median nerve.

The proximal amplitude of the median M-response varied from 2.0 to $9.6 \mathrm{mV}(4.6 \pm 2.4 \mathrm{mV})$. Only one patient, the one mentioned above, demonstrated an amplitude of $2.0 \mathrm{mV}$.

The distal latency of the M-response recorded from the $m$. abductor digiti minimi (ulnar nerve) was within the range of 2.3 to $4.5 \mathrm{msec}$, average $2.9 \pm 0.5 \mathrm{msec}$. The proximal latency of the M-response from this muscle varied between 5.8 and $7.9 \mathrm{msec}(7.2 \pm 0.9 \mathrm{msec})$. The conduction velocity via the ulnar nerve varied between 52.0 and $80.6 \mathrm{~m} / \mathrm{sec}(58.8 \pm 8.2 \mathrm{~m} / \mathrm{sec})$. The distal amplitude of the ulnar M-response was within the range from 1.8 to $10.5 \mathrm{mV}$ (mean $6.6 \pm 2.4 \mathrm{mV}$ ), and there was one patient with a distal amplitude of $1.8 \mathrm{mV}$. The proximal amplitude of the ulnar M-response was from 4.0 to $9.2 \mathrm{mV}(5.7 \pm 1.5 \mathrm{mV})$.

The minimum latencies of the $\mathrm{F}$-wave for the median nerve varied from 22.5 to $33.0 \mathrm{msec}$ (mean $26.64 \pm$ $\pm 2.2 \mathrm{msec}$ ). In one patient, a minimal F-wave latency over $33.0 \mathrm{msec}$ was observed, and the frequency of occurrence of the F-wave in this patient was only $30 \%$. One patient had an F-wave latency of $22.5 \mathrm{msec}$. In all other patients, the F-wave latencies were within the normal range, 24.4 to $28.8 \mathrm{msec}$ [8].

The frequency of F-wave occurrence in the median nerve varied from 30 to $100 \%$ (average $77.1 \pm 25.4 \%$ ). In 20 patients, the F-wave recorded from the median nerve was found in about $80 \%$ of the cases, while in 15 patients this wave was recorded in all cases (Fig. 1).

The amplitude of the median $\mathrm{F}$-wave varied from 0.35 to $1.2 \mathrm{mV}$ (mean $0.68 \pm 0.27 \mathrm{mV}$; Fig. 2).

The minimum latencies of the F-wave for the ulnar nerve were from 22.2 to $30.7 \mathrm{~ms}$ (mean $26.9 \pm 2.4 \mathrm{msec}$ ). Two patients demonstrated F-wave latencies shorter than the norm (22.2 and $23.5 \mathrm{msec})$. In other patients, this index was within the normal range (25.4 to $29.8 \mathrm{msec}[8])$.

The frequency of $\mathrm{F}$-waves from the ulnar nerve varied between 40 to $100 \%$, with mean $79.1 \pm 28.8 \%$. In 22 patients, the $\mathrm{F}$-wave from the ulnar nerve was

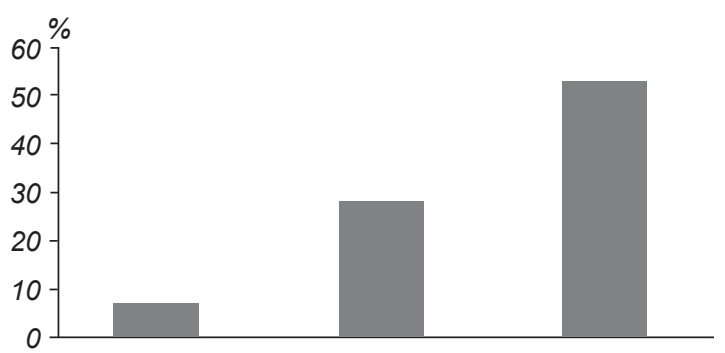

F i g. 1. Distribution of the frequency of generation of the median F-waves.

P и с. 1. Розподіл частот генерації F-хвиль при стимуляції n. medianus. 


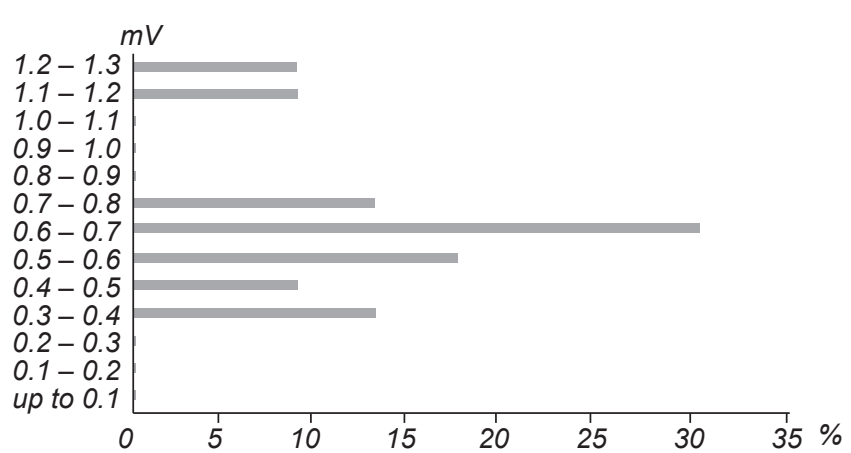

F i g. 2. Distribution of the amplitude of the median F-waves.

Р и с. 2. Розподіл амплітуд F-хвиль при стимуляції $n$. medianus.

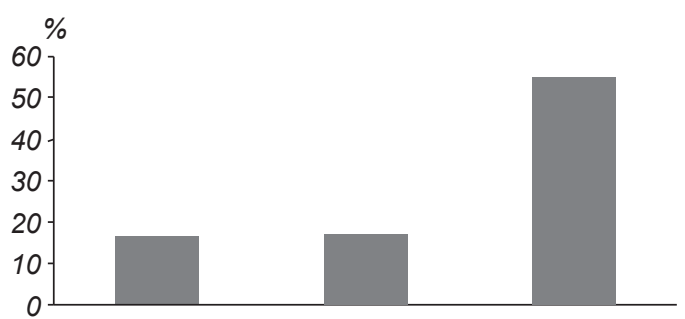

F i g. 3. Distibution of the frequency of generation of the ulnar F-waves.

P и с. 3. Розподіл частот генерації F-хвиль при стимуляції n. ulnaris.

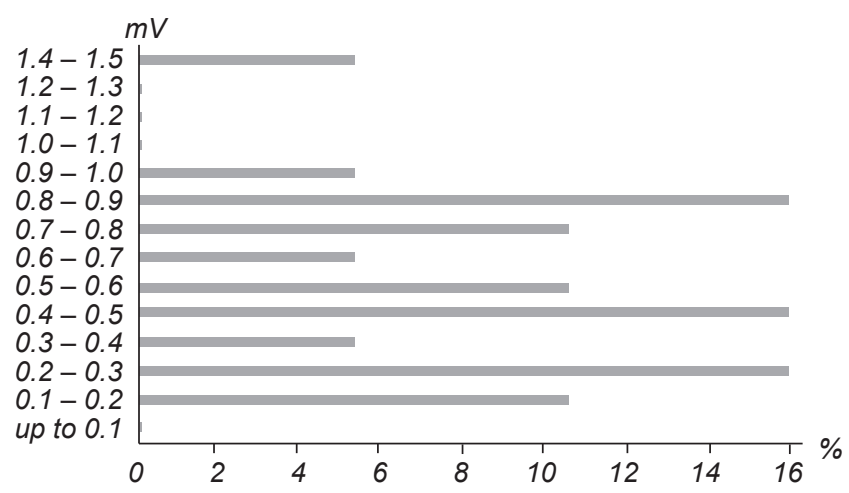

F i g. 4. Distribution of the amplitude of the ulnar F-waves.

Р и с. 4. Розподіл амплітуд F-хвиль при стимуляції $n$. ulnaris.

registered in about $80 \%$ or more, while in 16 subjects it was found in $100 \%$ of the patients (Fig. 3). The amplitude of the ulnar F-wave varied from 0.19 to 1.4 $\mathrm{mV}(0.58 \pm 0.32 \mathrm{mV}$; Fig. 4).

The mean median nerve F-wave latency was $26.6 \pm$ $\pm 2.2 \mathrm{msec}$ and did not differ significantly $(P=$ $=0.912$ ) from the values described in the literature [8]. The mean amplitude of this wave $(0.68 \pm 0.27 \mathrm{mV})$, however, differed significantly $(P<0.0001)$ from the mean value of this amplitude mentioned in the literature $(0.3 \mathrm{mV})$.
The average value of the ulnar $\mathrm{F}$-wave minimum latency was $26.9 \pm 2.4 \mathrm{msec}$ and did not differ significantly $(P=0.111)$ from the "normal" described value (27.6 msec [8]). The mean value of the ulnar F-wave amplitude $(0.58 \pm 0.32 \mathrm{mV})$ also differed significantly $(P<0.0001)$ from the reported data (0.15-0.2 mV).

In summary, almost all observed M-responses in our sampling were, according to their latencies and amplitudes, within the normal range. The same can be said of the conduction velocity along both examined nerves. Only one patient (2.8\% of the sampling) demonstrated a prolonged F-wave minimum latency. There were no patients with pathologically low F-wave amplitudes. The mean values of the F-wave amplitude in PTD patients were, for both the median and ulnar nerves, significantly higher than the mean normal amplitude values described in the literature (even higher than the maximum mentioned values). The frequency of generation of F-waves in PTD patients was noticeably greater than the norm; for the median nerve, it was about $55.6 \%$, while that for the ulnar nerve was about $58.3 \%$.

\section{DISCUSSION}

The amplitude and frequency of the F-waves can be considered EMG indicators for the excitability of motoneurons $[7,8]$. The characteristics of F-waves change under conditions where there are some central neuronal lesions. In the cases where motoneurons are characterized by hyperexcitability, F-waves demonstrate longer durations and increased amplitudes and frequencies [9, 10]. The F-wave amplitude, however, may increase also at peripheral nerve lesions $[8,11]$. In our sampling, there was one patient with "giant" median and ulnar F-waves, but generated with a significantly lower frequency; this case was related to the presence of a cervical pathology.

Using surface electromyography, Wohlfarth et al. [12] investigated patients with torticollis and graphospasm before and after applications of botulinum toxin. The authors found unchanged M-responses and conduction velocities, but shorter minimum and average F-wave latencies and higher F-wave amplitudes before the botulinum toxin treatment. The authors [12] explain modifications of the F-wave amplitude and latency as results of alterations in the system of recurrent inhibition. Administrations of a few myorelaxants (baclofen, 
tetrazepam, tizanidine, etc.) could also change the parameters of F-waves, mostly their amplitude and duration [13-16].

According to our results it can be said that the amplitude and, to some extent, frequency of occurrence, rather than latency of F-waves, are important indices in the studies of patients with PTD. Increased amplitude and frequency of these EMG phenomena reveal the existence of changes in the excitability of the respective alpha motoneurons. This phenomenology can be accepted as a measure of disturbances in segmental interneuronal networks, caused probably by alterations in the suprasegmental control mechanisms under conditions of PTD.

Informed written consent was obtained from all subjects involved in the tests and from attending physicians. All experimental protocols were in agreement with the internationally accepted ethical norms and with the guidelines of the Ethics Committe of the UMHATNP "St. Naum," Sofia, Bulgaria.

The authors of this study, N. Semerdjieva, D. Atanasova, G. Hranov, and I. Milanov, confirm that the research and publication of the results were not associated with any conflicts regarding commercial or financial relations, relations with organizations and/or individuals who may have been related to the study, and interrelations of co-authors of the article.

\section{Н. Семерджієва ${ }^{l}$, Д. Атанасова ${ }^{1}$, Г. Гранов ${ }^{1}$, І. Міланов ${ }^{1}$}

\section{F-ХВИЛЯ У ВЕРХНІХ КІНЦІВКАХ ПАЦІЕНТІВ ІЗ ПЕРВИННОЮ ТОРСІОННОЮ ДИСТОНІЄЮ}

${ }^{1}$ UMHATNP “Св. Наум”, Софія (Болгарія).

P е 3 ю м е

Ми досліджували характеристики F-хвилі в нервах верхніх кінцівок пацієнтів, що страждали на первинну торсіонну дистонію (ПТД); використовували стандартну техніку електроміографії з відведенням поверхневими електродами. Застосовували поодинокі супрамаксимальні електричні стимули для отримання оптимальних М-відповідей $m$. abductor policis brevis (подразнення $n$. medianus) та $m$. abductor digiti minimi (подразнення $n$. ulnaris); F-хвилі відводили на рівні зап’ястка. В цілому зареєстровані латентні періоди та амплітуди М-відповідей, як і швидкості проведення по досліджених нервах, не демонстрували драматичних відхилень від нормальних діапазонів значень. Середні амплітуди F-хвиль у $n$. medianus та $n$. ulnaris були вищими, ніж описані в літературі. Частота реєстрації
F-хвиль в обох нервах була вищою, ніж у нормі. Згідно 3 нашими результатами, амплітуда та (до деякої міри) частота реєстрації F-хвиль є параметрами, що заслуговують на увагу при обстеженні пацієнтів із ПТД. Вищі значення амплітуд та частоти виникнення F-хвиль вказують на зміни збудливості альфа-мотонейронів. Такі значення можуть розглядатись як показники дисбалансу в інтернейронних системах, вірогідно, пов'язані зі зрушеннями в механізмах супрасегментарного контролю при ПТД.

\section{REFERENCES}

1. J. Jankovic and S. Fahn, "Dystonic disorders," in: Parkinson's Disease and Movement Disorders, J. Jankovic, E. Tolosa (eds.), Lippincott, Williams and Wilkins (2002), pp. 331-351.

2. T. Warner, "Dystonia," in: Birmingham Movement Disorders Course, Mov. Disord. Soc., (2008), pp. 267-279.

3. A. Albanese, M. P. Barnes, K. P. Bhatia, et al., "A systematic review on the diagnosis and treatment of primary (idiopathic) dystonia and dystonia plus syndromes: report of an EFNS/ MDS-ES Task Force," Eur. J. Neurol., 13, No. 5, 433-444 (2006).

4. M. A. Fisher, "Are H reflexes and F responses equally sensitive to changes in motoneuronal excitability?" Muscle Nerve, 19, No. 10, 1345-1346 (1996).

5. M. A. Fisher, "H reflexes and F waves: physiology and clinical indications," Muscle Nerve, 15, No. 11, 1223-1233 (1992).

6. M. G. Espiritu, C. S. Lin, and D. Burke, "Motoneuron excitability and the F wave," Muscle Nerve, 27, No. 6, 720727 (2003).

7. B. Ishpekova, I. Milanov, and L. Hristova, Clinical Electromyography [in Bulgarian], Unison Art, Sofia (2003).

8. J. Kimura, Electrodiagnosis in Diseases of Nerve and Muscle. Principles and Practice, Edit. 3, Oxford Univ. Press (2001).

9. H. Matsumoto and Y. Ugawa, "Clinical signs, neurophysiological evaluation, and medication of spasticity review," Brain Nerve, 60, No. 12, 1409-1414 (2008).

10. B. Fierro, D. Raimondo, and A. Modica, "Analysis of F response in upper motoneurone lesions," Acta Neurol. Scand., 82, No. 5, 329-334 (1990).

11. M. A. Fisher, "The contemporary role of F-wave studies. F-wave studies: clinical utility," Muscle Nerve, 21, No. 8, 1098-1101 (1998).

12. K. Wohlfarth, M. Schubert, B. Rothe, et al., "Remote F-wave changes after local botulinum toxin application," Clin. Neurophysiol., 112, No. 4, 636-640 (2001).

13. J. Dressnandt, C. Auer, and B. Conrad, "Influence of baclofen upon the alpha-motoneurons in spasticity by means of F-wave analysis," Muscle Nerve, 18, No. 1, 103-107 (1995).

14. I. Milanov, "Mechanisms of baclofen action on spasticity," Acta Neurol. Scand., 85, 305-310 (1992)

15. I. Milanov, "Mechanisms of tetrazepam action on spasticity," Acta Neurol. Belg., 85, No. 5, 305-310 (1992).

16. I. Milanov and D. Georgiev, "Mechanisms of tizanidine action on spasticity," Acta Neurol. Scand., 89, No. 4, 274-279 (1994). 